\title{
Gillnet catchability of brown trout Salmo trutta is highly dependent on fish size and capture site
}

\author{
Reidar Borgstrom', Knut Bergum', Trond Erik Borresen' and Martin-A. Svenning ${ }^{2}$
}

\begin{abstract}
Borgstrøm R, Bergum K, Børresen TE and Svenning M-A. 2019. Gillnet catchability of brown trout Salmo trutta is highly dependent on fish size and capture site. Fauna norvegica 39: 30-38.

Use of experimental gillnet fleets is common both in scientific studies of fish populations and in fish sampling for management purposes. Fish catchability may vary considerably with fish and gillnet mesh size, and catches obtained by gillnet fleets composed of nets with different mesh sizes may give length and age distributions that deviate considerably from the length and age structure of the population. We have estimated the absolute catchability of allopatric brown trout (Salmo trutta) in the littoral and pelagic habitat of a small lake based on a mark-recapture experiment. The brown trout catchability varied considerably both with fish size and habitat type, probably due to a size-related variation in swimming distance per time unit and a size-related use of the different lentic habitats. The sampling bias in experimental gillnet fishing may be reduced by operating the gillnet fleets in all possible lentic habitats and most fundamentally, by use of catchability data obtained from populations with 'known' length and age structures. By reducing this sampling bias, more realistic estimations of the age and length distribution for a given population will be possible.
\end{abstract}

doi: 10.5324/fn.v39i0.2536. Received: 2018-05-16. Accepted: 2019-03-01. Published online: 2019-05-10. ISSN: $1891-5396$ (electronic).

Keywords: Gillnet selection, lake, annual mortality, sampling strategy

1. Faculty of Environmental Sciences and Natural Resource Management, Norwegian University of Life Sciences, P.O. Box 5003, NO-1432 As, Norway

2. Norwegian Institute of Nature Research (NINA), Arctic Ecology Department, Fram Center, P.O. Box 6606 Langnes, NO-9296 Tromsø, Norway

Corresponding author: Reidar Borgstrøm

E-mail: reidar.borgstrom@nmbu.no

\section{INTRODUCTION}

Gillnets are used both in subsistence and commercial freshwater and saltwater fisheries worldwide as well as in fish population surveys to obtain data on age and size structure and relative fish abundance (Degerman et al. 1988; Appelberg et al. 1995; Hovgård \& Larssen 2000). The size-related relative catchability of a given fish species is frequently computed by assuming that all gillnet mesh sizes capture the same fraction of the fish present at their respective maximum modal lengths (McCombie \& Fry 1960; Regier \& Robson 1966; Ricker 1975, Kurkilahti et al. 1998, and references therein). Using this assumption, a fleet of gillnets may be constructed which theoretically give equal catchability for all fish within a given length interval
(Regier \& Robson 1966; Jensen 1977; Hamley 1980). However, such assumed ideal gillnet fleets seldom exist because absolute catchability may vary considerably with fish size and mesh size, as well as between species (Hamley \& Regier 1973; Hamley 1975; 1980; Borgstrøm 1989; Jensen 1995). Extensive summaries of factors producing bias in gillnet sampling are presented by e.g. Hamley $(1975 ; 1980)$.

Analysis of population structure and annual growth and survival rates are often based on age and length composition in experimental gillnet catches (Jensen 1977). However, where knowledge of the absolute catchabilities is limited, obtained catch data may give restricted information regarding relative and absolute abundance of age- and length-classes in population 
(O'Grady 1981). Nevertheless, the recommended composition of gillnet fleets has been based on the hypothesis that maximum catchability is constant, irrespective of mesh size (Jensen 1977; Jensen 1990; Kurkilahti \& Rask 1996, Kurkilahti et al. 1998, and references therein). Alternatively, absolute catchability estimates have been obtained by sampling populations where abundance and length structure are 'known' from previous mark-recapture studies (e.g., Hamley \& Regier 1973; Borgstrøm 1989; Borgstrøm \& Plahte 1992) and from fishing stocked fish (O'Grady 1981; Jensen 1995; Jensen \& Hesthagen 1996). Borgstrøm \& Plahte (1992) estimated the gillnet selectivity of brown trout (Salmo trutta) by a mark-recapture experiment carried out on individuals in a dense population. In the present study, a similar experiment was repeated in the same lake. However, we also included smaller mesh sizes in the gillnet fleet to study both the size-related variation in habitat use and the catchability of brown trout over a broader length interval. We expected large variation in catchability, dependent on fish size and capture site due to a size-related variation in swimming activity and habitat use.

\section{MATERIAL AND METHODS}

Population estimation by a mark-recapture experiment in combination with a study of gillnet catchability was performed in Lake Løyningsvatn (hereafter called Løyningsvatn), situated $595 \mathrm{~m}$ a. s. 1. in Western Norway $\left(5^{\circ} 55^{\prime} \mathrm{N}, 6^{0} 40^{\prime} \mathrm{E}\right)$ (Borgstrøm 1994). The lake is oligotrophic with Secchi disc transparency between 10 and $14 \mathrm{~m}$ during summer. It has a surface area of $0.49 \mathrm{~km}^{2}$, maximum depth of c. $45 \mathrm{~m}$ and mean depth of c. 14.7 $\mathrm{m}$ (Borgstrøm 1994). Ice break-up is usually at the end of May. Brown trout is the only fish species in the lake.

The number of brown trout in the lake was estimated by a mark-recapture experiment. Between 24 and 29 June 2000, individuals were captured using a beach seine and electrofishing, and subsequently marked. The beach seine was $50 \mathrm{~m}$ in length, $4 \mathrm{~m}$ in height and with mesh size $3 \mathrm{~mm}$ at the cod end. Seining was carried out at all possible shore sections with suitable bottom substrate (Figure 1a). In the innermost part of the littoral zone, along roughly the same sections, sampling by electrofishing was performed by a pulsed DC backpacker produced by engineer Paulsen, Trondheim. After capture, all fish were anesthetized with Nyco fruitsalt (containing $\mathrm{NaHCO}_{3}$ ), total length was measured to the nearest millimeter, and after marking by removal of the adipose fin the fish were kept in a water tank for observation until recovery. All fish recovered a few minutes after the treatment and were released at the capture site. Since fishing in the lake is open for the public, we did not want to use chemicals other than fruitsalt for anesthetization. A total of 1413 brown trout were captured; 1132 by beach seine and 81 by electrofishing (Figure 2a).

The recapture of marked fish in the population was carried out between 1 and 14 July using fleets of littoral and pelagic gillnets. The gillnets were set in the evening and lifted the next morning after c. $12 \mathrm{hrs}$. All gillnets were made of light grey monofilament thread and had a hanging coefficient of 0.5 , twine diameter $0.20 \mathrm{~mm}$ and one mesh size per net. The littoral nets were $25 \mathrm{~m}$ in length and $1.5 \mathrm{~m}$ in height and with mesh sizes 10, 12, 16.5, 19.5, 22.5, 26, 29, 35, 39, and $45 \mathrm{~mm}$ (bar mesh). Each net was set from nearby land, facing outwards and approximately perpendicular to the shore. The pelagic gillnets consisted of mesh sizes 16.5, 19.5, 22.5, 26, 29, and $35 \mathrm{~mm}$ and were $25 \mathrm{~m}$ in length and $6 \mathrm{~m}$ in height. Each pelagic setting consisted of three nets with different mesh sizes tied together in a gang. The mesh size composition in these gangs was changed from night to night. In Table 1, the total effort in gillnet nights is given for each mesh size and gillnet type. To obtain a random catch and control for marks in the littoral area, the lake shore line was divided into seven sections and the littoral gillnets were set in random order within each section (mesh size setting order was decided by lottery every day) (Figure 1b). Correspondingly, the pelagic gillnet gangs were set from the surface in the open water over depths c. $>10 \mathrm{~m}$ and covering the different parts of the pelagic area (Figure 1b). The gillnet locations in both littoral and pelagic areas were used twice, giving a total effort of 242 gillnet nights (gillnet area $8925 \mathrm{~m}^{2}$ ) in the littoral area (c. $0.21 \mathrm{~km}^{2}$ inside the $10 \mathrm{~m}$ depth contour), and 84 gillnet nights (gillnet area $12600 \mathrm{~m}^{2}$ ) in the pelagic area (c. $0.28 \mathrm{~km}^{2}$ outside the $10 \mathrm{~m}$ depth contour) (Table 1). As the total gillnet effort used in the littoral and pelagic area are nearly proportional to the areas of the two habitats, the condition for random sampling is fulfilled (Ricker 1975). All gillnetted fish ( $\mathrm{n}=1454)$ were controlled for marks, had their total length measured to nearest millimeter, and had their otoliths sampled for age determination. In the laboratory, the otoliths from a random sample from each cm-class (548 trout) were cut in half through the centre and each half was burnt separately before age determination was performed under a stereomicroscope (Christensen 1964; Borgstrøm et al. 2010).

The number of trout in the length-classes $\left(\mathrm{L}_{\mathrm{j}}\right) 8.0-9.9$ cm, $10.0-11.9 \mathrm{~cm}, 12.0-13.9 \mathrm{~cm}, 14.0-15.9 \mathrm{~cm}, 16.0-17.9$ $\mathrm{cm}, 18.0-19.9 \mathrm{~cm}, 20.0-21.9 \mathrm{~cm}$, and $22.0-23.9 \mathrm{~cm}$ were estimated according to the Petersen method with Chapman's version, i.e.,

$$
\begin{aligned}
& N=(M+1)(C+1) /(R+1)(\text { Ricker } 1975), \text { where: } \\
& N=\text { estimated number of fish in } L_{j} \\
& M=\text { number of marked fish in } L_{j} \\
& C=\text { number of gillnetted fish in } L_{j} \text { controlled for marks } \\
& R=\text { number of recaptures in } L_{j}
\end{aligned}
$$

Approximate confidence limits of the estimates were obtained by using $\mathrm{R}$ as the entering variable in a Poisson frequency distribution, presented in Appendix II in Ricker (1975).

Direct estimation of numbers in length-class $24.0-25.9 \mathrm{~cm}$ was not possible due to the low number of marked individuals in 
A

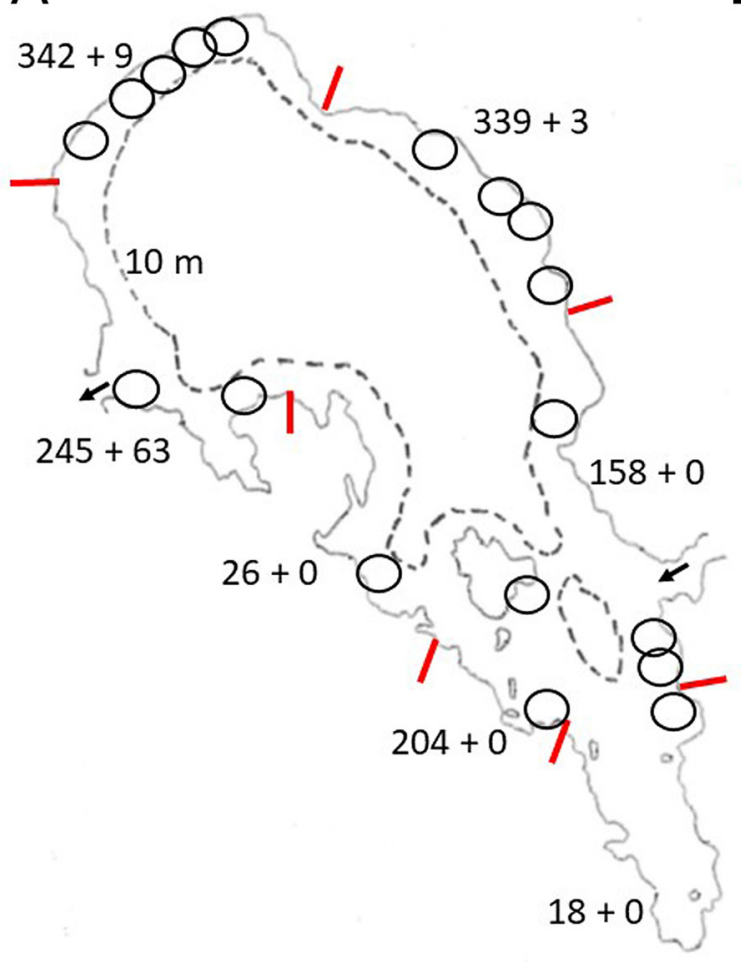

B

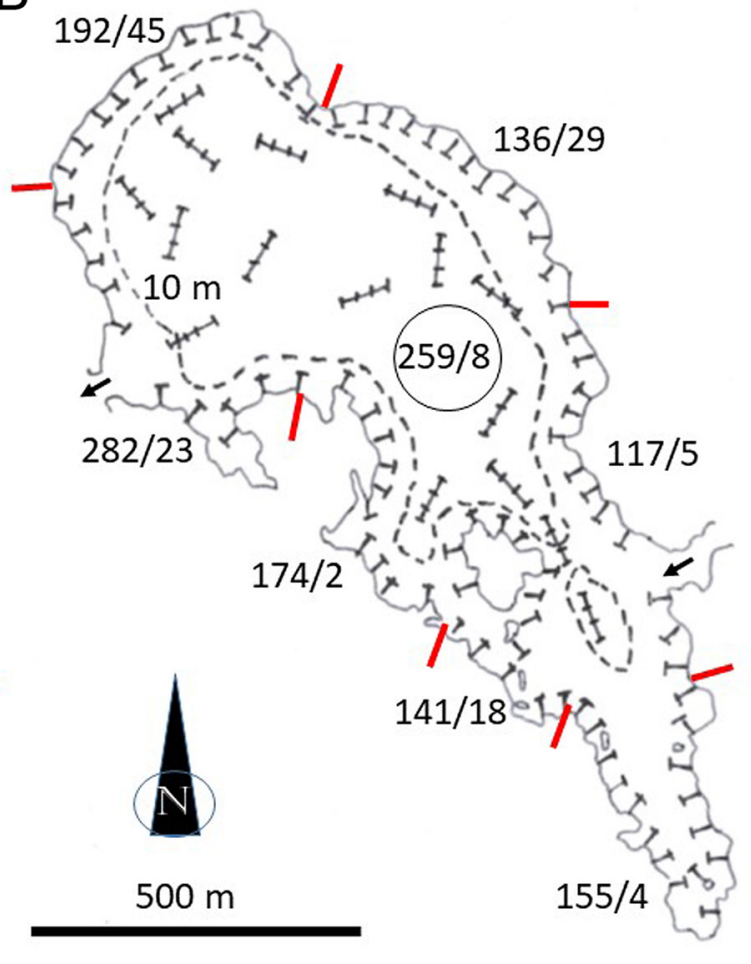

Figure I. 1A. Map of Lake Løyningsvatn with beach seine locations indicated by a circle. X $+Y$ denote number of marked fish after capture by beach seine + electrofishing in the seven sections of the littoral zone. 1B. Littoral and pelagic gillnet locations, with $\mathrm{X} / \mathrm{Y}$ denoting number of controlled fish/ recaptures in each littoral section and in the pelagic area.

Table I. Number of gillnet nights and total catch by each mesh size of littoral and pelagic gillnets used during the mark-recapture experiment in Lake Løyningsvatn 1 - 14 July 2000. Asterisk (*) indicates gillnets that had been used 18 - 22 June.

\begin{tabular}{lllllll}
\hline $\begin{array}{l}\text { Mesh size } \\
(\mathrm{mm})\end{array}$ & $\begin{array}{l}\text { Effort (littoral } \\
\text { gillnet nights) }\end{array}$ & $\begin{array}{l}\text { Effort (pelagic } \\
\text { gillnet nights) }\end{array}$ & $\begin{array}{l}\text { Total catch by } \\
\text { littoral gillnets }\end{array}$ & $\begin{array}{l}\text { Total catch by } \\
\text { pelagic gillnets }\end{array}$ & $\begin{array}{l}\text { Catch per littoral } \\
\text { gillnet night }\end{array}$ & $\begin{array}{l}\text { Catch per pelagic } \\
\text { gillnet night }\end{array}$ \\
\hline 10 & 40 & $3^{*}$ & 161 & 0 & 4.0 & 0 \\
12 & 40 & $3^{*}$ & 557 & 0 & 13.9 & 0 \\
16.5 & 26 & 14 & 259 & 14 & 10.0 & 1.0 \\
19.5 & 26 & 14 & 148 & 118 & 5.7 & 8.4 \\
22.5 & 26 & 14 & 46 & 125 & 1.8 & 8.9 \\
26 & 26 & 14 & 10 & 1 & 0.4 & 0.1 \\
29 & 26 & 14 & 11 & 1 & 0.4 & 0.1 \\
35 & 24 & 14 & 4 & 0 & 0.2 & 0 \\
39 & 4 & - & 0 & - & & \\
45 & 4 & - & 1 & & & \\
\hline Sum & 242 & 84 & 1197 & 259 & - & - \\
\hline
\end{tabular}


this length-class $(\mathrm{n}=15)$, the low number of individuals caught in gillnets $(n=8)$ and lack of recaptures. Accordingly, the number of fish in this length-class was estimated by assuming equal beach seine catchability of fish in this length-class and length-class $22.0-23.9 \mathrm{~cm}$. Since the experiment lasted for only a few weeks and there was very little fishing activity in the lake except for our experiment, it is assumed that mortality as well as growth in length did not change the population structure between marking and recapture.

The catchability of brown trout was estimated according to Lagler (1968) as

$$
\begin{aligned}
& \mathrm{q}_{\mathrm{ij}}=\mathrm{C}_{\mathrm{ij}} / \mathrm{f}_{\mathrm{i}} * \mathrm{~N}_{\mathrm{j}} \text {, with } \\
& \mathrm{q}_{\mathrm{ij}}=\text { catchability of length-class } \mathrm{j} \text {, in mesh size } \mathrm{i} \\
& \mathrm{f}_{\mathrm{i}}=\text { total effort with mesh size } \mathrm{i} \\
& \mathrm{C}_{\mathrm{ij}}=\text { number of fish in length-class } \mathrm{j} \text { captured by mesh } \\
& \text { size } \mathrm{i} \\
& \mathrm{N}_{\mathrm{j}}=\text { estimated total number of fish in length-class } \mathrm{j} \text { in the } \\
& \text { population }
\end{aligned}
$$

As described by Ricker (1975), simple catch curves for estimation of instantaneous mortality rate $(\mathrm{Z})$ and annual survival rate (S) were obtained by plotting the logarithms of numbers of successive age-classes $\geq 6$ winters captured per ten gillnet fleets, with each fleet consisting of both littoral and pelagic gillnets with the mesh sizes 10, 12, 16.5. 19.5, and 22.5 $\mathrm{mm}$. Linear regressions were then used to compute $\mathrm{Z}$ (equal to the regression coefficient), and the annual survival rate estimated by $\mathrm{S}=\mathrm{e}^{-\mathrm{Z}}$.

\section{RESULTS}

\section{Population abundance and length distribution}

According to the beach seine and gillnets catches, the population

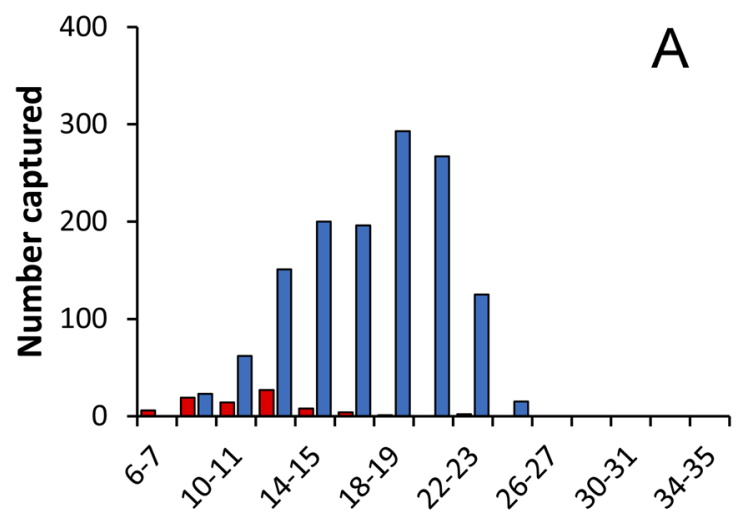

Length-class (cm)

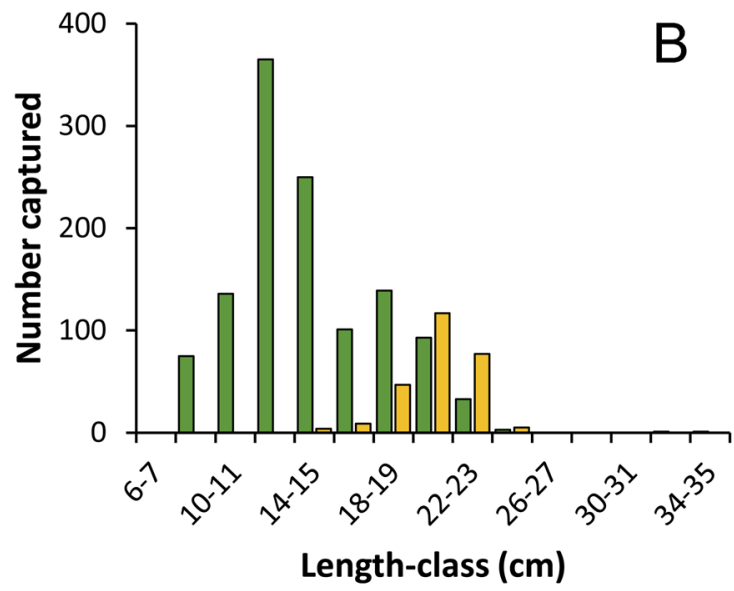

Figure 2. A. Length distribution of captured brown trout by electrofishing (red) and beach seining (blue), and subsequently marked and released in Lake Løyningsvatn at the end of June 2000, and B. length distribution of fish captured by littoral (green) and pelagic (yellow) gillnets in beginning of July 2000 and controlled for recaptures.

Table 2. Number marked, number captured by gillnets and controlled for marks, number recaptured, and estimated number of brown trout in two-cm length-classes from 8.0 to $23.9 \mathrm{~cm}$ by the Petersen mark-recapture method in Lake Løyningsvatn, 24 June - 14 July 2000.

\begin{tabular}{llllllllll}
\hline & \multicolumn{8}{c}{ Number captured and controlled (C) } & \multicolumn{3}{c}{ Number recaptured (R) } & Estimated & $\begin{array}{l}\text { Confidence } \\
\text { Length-class } \\
(\mathrm{cm})\end{array}$ & $\begin{array}{l}\text { Number } \\
\text { marked (M) }\end{array}$ & Littoral nets & Pelagic nets & Total & Littoral nets & Pelagic nets & Total & $\begin{array}{l}\text { number (N) } \\
\text { limits }(0.95)\end{array}$ \\
\hline $8.0-9.9$ & 42 & 75 & 0 & 75 & 3 & 0 & 3 & 817 & $333-2042$ \\
$10.0-11.9$ & 76 & 136 & 0 & 136 & 9 & 0 & 9 & 1055 & $583-2110$ \\
$12.0-13.9$ & 178 & 365 & 0 & 365 & 29 & 0 & 29 & 2184 & $1538-3211$ \\
$14.0-15.9$ & 208 & 250 & 4 & 254 & 29 & 0 & 29 & 1777 & $1251-2611$ \\
$16.0-17.9$ & 200 & 101 & 9 & 110 & 16 & 1 & 17 & 1240 & $791-2047$ \\
$18.0-19.9$ & 294 & 139 & 47 & 186 & 19 & 2 & 21 & 2508 & $1672-3940$ \\
$20.0-21.9$ & 267 & 93 & 117 & 210 & 18 & 2 & 20 & 2693 & $1778-4284$ \\
$22.0-23.9$ & 127 & 33 & 77 & 110 & 3 & 3 & 6 & 2030 & $1008-4440$ \\
$24.0-25.9$ & 15 & 3 & 5 & 8 & 0 & 0 & 0 & - & - \\
\hline Sum & 1407 & 1195 & 259 & 1454 & 126 & 8 & 134 & 14304 & - \\
\hline
\end{tabular}




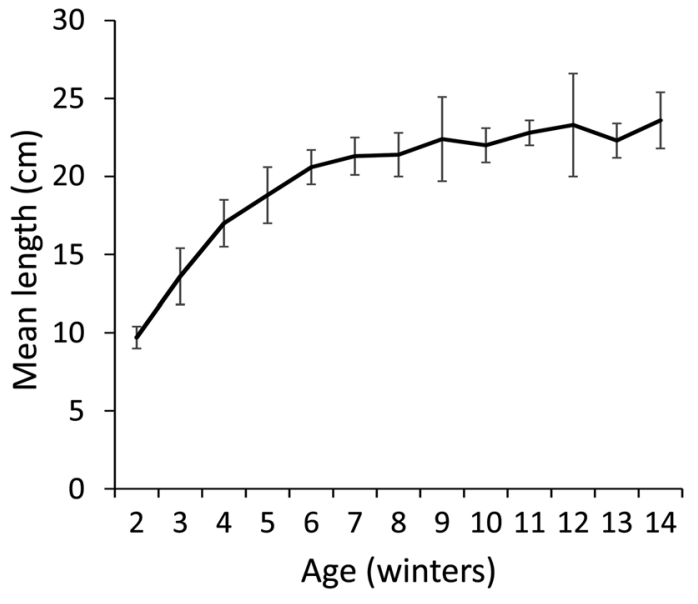

Figure 3. Mean empiric length of age-class $2-14$. Vertical bars denote SD of mean length.

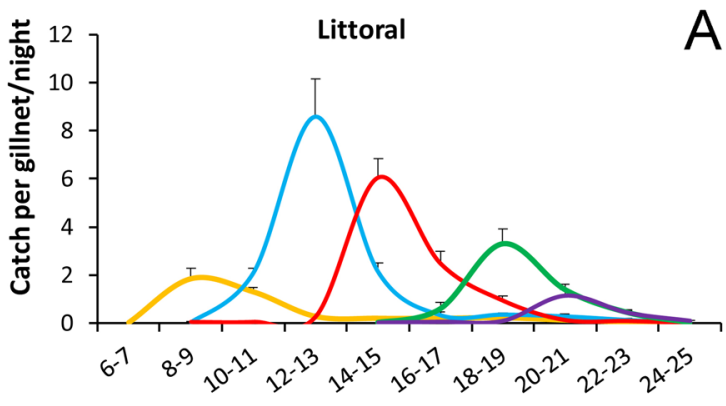

Length-class $(\mathrm{cm})$

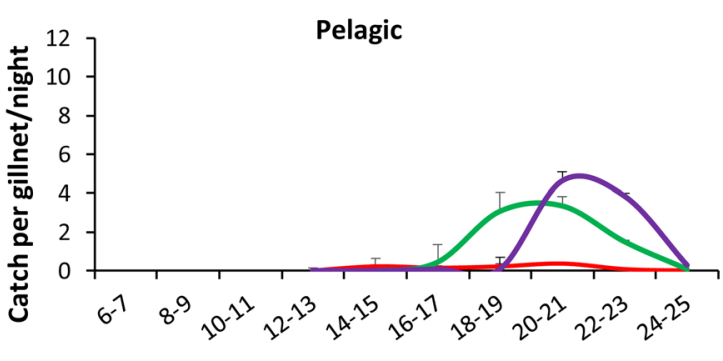

Length-class $(\mathrm{cm})$

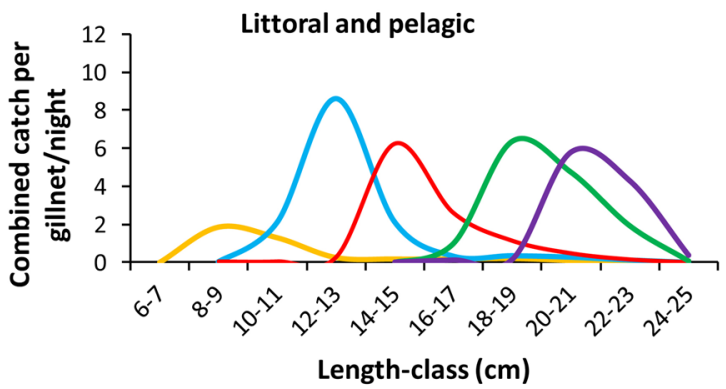

is characterized by fish with length $<26 \mathrm{~cm}$ (Figure 2ab). In the pelagic gillnets, 259 fish were captured, of which the largest was $25.6 \mathrm{~cm}$. In the littoral gillnets, 1197 fish were captured and all but two were $\leq 25.9 \mathrm{~cm}$ in length (Figure $2 \mathrm{~b}$ ). The two fish $>25.9 \mathrm{~cm}$ were $32.0 \mathrm{~cm}$ and $35.7 \mathrm{~cm}$ in length, and the smallest was a cannibal having eaten two brown trout with total length $7 \mathrm{~cm}$ and $8 \mathrm{~cm}$.

The population estimate for brown trout in the length-class $8.0-23.9 \mathrm{~cm}$ was 14304 individuals (Table 2). Length-classes $18.0-19.9 \mathrm{~cm}$ and $20.0-21.9 \mathrm{~cm}$ were the most numerous, both having estimates of $>2500$ individuals. The number of individuals in length-class $24.0-25.9 \mathrm{~cm}$ was estimated to be 170 (basic data in Table 2). The population estimate for fish in length-class 8.0 - $25.9 \mathrm{~cm}$ was 14474 or $295 \mathrm{ha}^{-1}$.
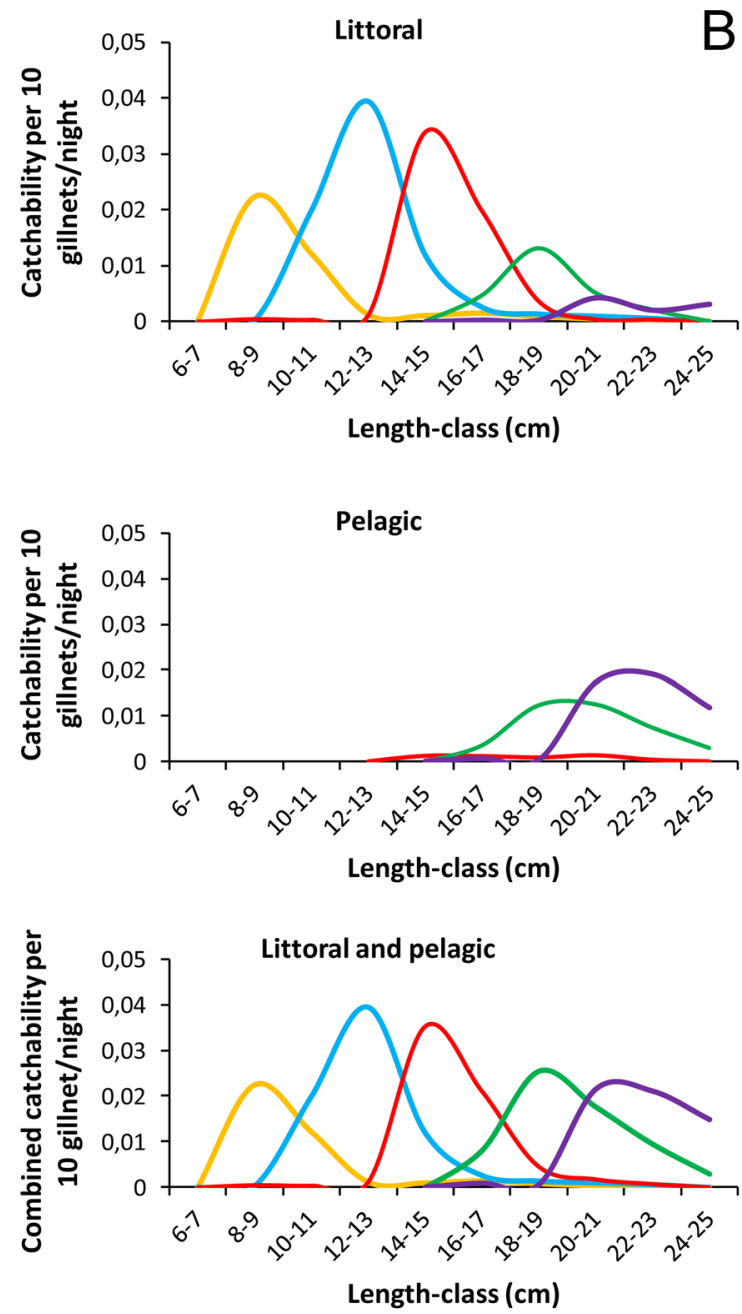

Figure 4. A. Mean catch per effort (gillnet night) by the mesh sizes 10, 12, 16.5, 19.5, $22.5 \mathrm{~mm}$ (bar mesh) of littoral gillnets and mesh sizes 16.5, 19.5, $22.5 \mathrm{~mm}$ (bar mesh) of pelagic gillnets in Lake Løyningsvatn, in first half of July 2000, with standard error of the daily means indicated by vertical bars. The area of each littoral and pelagic gillnet was $37.5 \mathrm{~m}^{2}$ and $150 \mathrm{~m}^{2}$, respectively. B. Mean estimated catchability per effort (ten gillnet nights) with the same mesh sizes set in littoral and pelagic parts of the lake. Mesh size $10 \mathrm{~mm}$ yellow, $12 \mathrm{~mm}$ blue, $16.5 \mathrm{~mm}$ red, $19.5 \mathrm{~mm}$ green, $22.5 \mathrm{~mm}$ lilac. The lines are smoothed by use of the 'smoothed line function' in Excel. 


\section{Length at age}

The 2-winter old individuals had a mean empiric length of $9.7 \pm$ SD $0.7 \mathrm{~cm}$. The empiric length stagnates from about age 7 with age-class 7 having a mean length of $21.3 \pm \mathrm{SD} 1.2 \mathrm{~cm}$, and ageclass 14 having a mean length of $23.6 \pm$ SD $1.8 \mathrm{~cm}$ (Figure 3). The mean annual length increment from age 7 to age 14 is only $0.3 \mathrm{~cm}$ and there is a large overlap in length between individuals in these age-classes (Figure 3).

\section{Catch and catchability per unit effort}

Catches in the five mesh sizes from 26 to $45 \mathrm{~mm}$ were in length-class $12.2-25.4 \mathrm{~cm}$ apart from one individual that had a body length of $35.7 \mathrm{~cm}$. The low catch $(\mathrm{n}=28$; Table 1$)$ in mesh sizes from $26 \mathrm{~mm}$ and larger did not allow for any analysis of catchabilities for these gillnet sizes.

For catches in littoral gillnets, both the number of individuals captured per unit effort (cpue) and catchability had a peak at mesh size $12 \mathrm{~mm}$. At larger mesh sizes, catch and catchability declined with increasing mesh size (Figure 4). Mesh size $10 \mathrm{~mm}$ had a considerably lower cpue and maximum catchability compared to mesh size $12 \mathrm{~mm}$ (Figure 4). In total, cpue and catchability showed opposite trends in the gillnets set in the littoral zone compared to gillnets set in the pelagic zone (Figure 4). There was no capture by mesh sizes 10 and $12 \mathrm{~mm}$ set in the pelagic area $18-22$ June, very low cpue and catchability with $16.5 \mathrm{~mm}$ and a substantial increase in cpue and catchability from mesh size $16.5 \mathrm{~mm}$ to $22.5 \mathrm{~mm}$ (Figure 4 and Table 1). According to the catches per gillnet area, the abundance of brown trout was considerably higher in the littoral area than in the pelagic area (Table 1). Only one fish per gill net night ( 0.7 fish per $100 \mathrm{~m}^{2}$ gillnet area) were captured by mesh size $16.5 \mathrm{~mm}$ in pelagic nets compared to 10 fish per gillnet night (26.6 fish per $100 \mathrm{~m}^{2}$ gillnet area) captured by the same mesh size used in the littoral area. In pelagic gillnets with mesh sizes $19.5 \mathrm{~mm}$ and $22.5 \mathrm{~mm}$, the catches per gillnet night (and gillnet area) were higher, but still much lower compared to catches obtained by littoral gillnets (Table 1).

\section{Annual survival rates}

When estimated number of fish in age-class 6 to 14 (based on the catch-recapture experiment) is plotted against age, the regression line has a coefficient of $Z=-0.322$ (instantaneous mortality rate) (Figure 5), corresponding to an annual survival rate of $\mathrm{S}=0.725$. The catch curves of the same age-classes obtained by fishing with the mesh sizes 10, 12, 16.5, 19.5, and $22.5 \mathrm{~mm}$ in the littoral and pelagic zones, give regression coefficients $Z=-0.179$ and $Z=-0.140$ respectively, corresponding to $\mathrm{S}=0.836$ and $\mathrm{S}=0.870$. By combining the catches in littoral and pelagic gillnets, a catch curve with a regression coefficient of $Z=-0.318$ is obtained, giving $S=0.727$, or nearly identical estimates of instantaneous mortality and annual survival rate as those obtained based on the estimated numbers in the population (Figure 5).

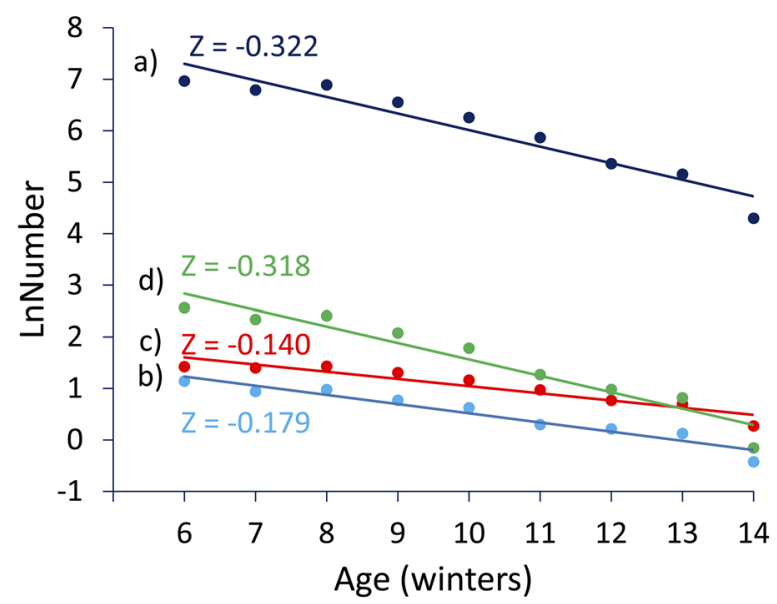

Figure 5. a) Ln estimated number in age-classes $6-14$, based on the mark-recapture experiment, with regression line and regression coefficient (Z). b-d) Ln numbers of each age-class captured per 10 gillnet fleet nights (with mesh sizes 10, 12, 16.5, 19.5. and 22.5 $\mathrm{mm}$, bar mesh) of respectively b) littoral nets, c) pelagic nets, and d) combined littoral and pelagic nets, with regression lines and coefficients (Z).

\section{DISCUSSION}

The decrease in littoral gillnet catchability with increasing fish length and mesh size, and the simultaneous increase in catchability in pelagic gillnets most probably indicate a change in habitat use with fish size. Small fish appear to mainly occupy the littoral zone and use the pelagic habitat more frequently as they become larger. Such habitat shifts related to fish size are commonly observed in allopatric brown trout populations (Haraldstad \& Jonsson 1983; Jonsson 1989; Schei \& Jonsson 1989), as well as in a wide variety of other fish species (Werner et al. 1983; Garcia-Berthou 2001; Klemetsen et al. 2003). In addition, fish size may also affect the catchability directly since there may be a positive relationship between swimming performance per time unit and fish size (Rudstam et al. 1984). Changes in catchability related to fish size as recorded in the present study have been reported for other fish species (Hamley \& Regier 1973; Hamley 1975; 1980; Borgstrøm 1989), as well as in studies with brown trout as target species (O'Grady 1981; Borgstrøm \& Plahte 1992; Jensen 1995).

The precision in all mark-recapture experiments depends on random sampling, and the application of the Petersen method is justified only when a number of conditions for random sampling are met, as listed in Ricker (1975). In our experiment, the marked fish were not randomly mixed with the unmarked since sampling for marking was only performed in the littoral zone and few recoveries of marked fish were obtained using pelagic gillnets. However, the recapture occurred in both the littoral and the pelagic areas of the lake, with a near proportional fishing effort in both habitats, making all marked fish as vulnerable 
to the fishing gear as the unmarked fish. In addition, the small standard errors of the daily means of both the littoral catches and the pelagic catches may indicate an even distribution of fish during the two weeks of gillnetting. The relatively low number of recaptures within some length-classes, with corresponding wide confidence limits of the estimated abundance resulted in uncertainty of length distribution and estimated numbers for these length classes. This uncertainty might have been better addressed by using the approach described by Woillez et al. (2016). However, our results are in keeping with the pattern in catchability (retention probability) related to fish size/mesh size as found by Borgstrøm and Plahte (1992). Their five-year study with mesh sizes $\geq 16.5 \mathrm{~mm}$ was carried out in the same lake, and supported the general trend of changes in catchability being related to fish size in this population consisting of small individuals with stunted growth at small length. Swimming performance per time unit is related to fish size (Rudstam et al. 1984), and thereby highly related to population abundance as observed in some brown trout populations. Jensen (1977) discovered a high stationarity in the brown trout population in the lake Øvre Heimdalsvatn characterized by high fish abundance and small-sized individuals. He estimated that an effort of 15 gillnets per ha was needed to capture $50 \%$ of the catchable fish in this population. In contrast, Sømme (1941) estimated that $>90 \%$ of catchable brown trout in the lake Langesjøtjønne were caught by an effort of c. 4 gillnets per ha. This population had a low density, consisting of large fish which obviously had a high swimming activity per time unit.

A considerable number of brown trout and other salmonid populations in Norway exhibit the same population characteristics as seen for brown trout in Løyningsvatn, having high recruitment potentials and stagnation in individual growth at short length (Amundsen 1988; Jonsson \& Borgstrøm 2000; Klemetsen \& Amundsen 2000; Amundsen et al. 2007). In such populations, gillnet catches may be restricted mostly to small mesh sizes and fish within a narrow length interval. As shown by our present study, even within the short length interval from approximately 10 to $25 \mathrm{~cm}$, small changes in fish length seem to result in marked differences in catchability, as well as leading to marked changes in habitat use.

In general, both food and habitat use change as fish become larger, and such niche shifts are often interpreted a consequence of changes in metabolic rates and limitation in food resources (Forseth et al. 1999). Predation risk relative to fish size is probably the main factor influencing at what size the niche shifts will be realised (Werner \& Hall 1988; L'Abée-Lund et al. 1993). In allopatric populations of lentic brown trout, cannibalism seems to be rare in fish $<25 \mathrm{~cm}$ (L'Abee-Lund et al. 1992; Borgstrøm et al. 2010). However, even a low number of potential cannibals may force smaller fish, vulnerable to predation to seek refuges (Werner et al. 1983; Werner \& Hall 1988; Svenning \& Borgstrøm 2005, Damsgård \& Ugedal 2006) where they stay until reaching a length whereby they are outside the predation risk window (Werner \& Hall 1988; L'Abee-Lund et al. 1992; Byström et al. 2003). Refuges may be found in both shallow and deep water, depending on fish species. Shallow water offers the most complex bottom, often with vegetation or stones providing hiding places for small fish (Werner $e t$ al. 1983; Museth et al. 2002; Byström et al. 2004; Svenning \& Borgstrøm 2005). By staying in an inferior habitat regarding food availability, and in addition spending less time in foraging in the presence of predators (Cerri \& Fraser 1983; Werner \& Hall 1988; L'Abée-Lund et al. 1993; Byström et al. 2004), the swimming activity per time unit may become low and become limited to a small water volume. The low catchability of small trout compared to larger fish in Løyningsvatn may thus be related to an antipredator behavior, with low swimming activity and dominant use of the shallowest part of the littoral zone. Consequently, the encounter probability of these size-classes towards gillnets set outward from the shore may become low compared to size-classes that also use deeper parts of the littoral zone or open water. Since the fraction of the population occupying the littoral zone versus the pelagic and profundal zone may vary with population density and fish size (Borgstrøm 1992; Sandlund et al. 1992; Klemetsen et al. 2002; Byström et al. 2004), the gillnet catchability of given size-classes may show variation due both to density and length composition of the fish stock. As our study indicates, habitat use and fish swimming behaviour may substantially affect catchabilities when fishing with passive gears like gillnets. Thus, the length and age frequencies in catches obtained by fishing with gillnet fleets do not reflect the population composition. This conclusion is probably valid irrespective of whether multimesh gillnets of the Nordic type (Appelberg et al. 1995) are used or single mesh gillnets as used in the present study.

The relative number of fish in each age-class captured by gillnet fleets are commonly used in construction of catch curves for estimation of annual survival (Ricker 1975). However, due to the high variation in catchability between age-classes, such catch curves may give biased annual survival rates with consequences for fishery management actions and fishery advice. In some countries (e.g., Norway), gillnet fleets used separately in the littoral zone or fleets used both in the littoral and/or pelagic areas have frequently been operated in so-called test fishing (see Jensen 1972; 1977; Qvenild \& Skurdal 1981). When no information regarding absolute catchabilities is available and equal maximum catchability or selectivity are assumed irrespective of mesh size and sampling location in the lake, the estimated length- and age-class distribution obtained by such sampling becomes biased, as indicated in the present study. However, in our study the difference in estimated annual survival based on the age composition in the combined catches from the littoral and pelagic area and the estimated age composition in the population was practically identical. This was due to the large overlap in length distribution between ageclasses $\geq$ six years, leading to small differences in catchabilities, irrespective age. In populations with a much wider length-class distribution, and thereby with large differences in catchabilities 
between length- and age-classes (Hamley 1980, and references therein), the bias in estimated survival rates based on ageclass composition in gillnet catches may be substantial. Since analyses of survival rates obtained by catches from gillnet fleets are commonly used as a basis for fishery management, these analyses may be improved by use of additional information such as age-specific annual growth and age-class numbers.

In conclusion, brown trout catchability varies considerably both with fish size, age, and habitat type, most probably due to a combination of a size-related use of the different lentic habitats and a size-related variation in swimming distance per time unit, influencing the probability of encountering the gillnets. To reduce sampling bias in experimental gillnet fishing, the gillnet fleet should be operated in all lentic habitats, and most fundamentally, catchability data obtained by fishing on populations with 'known' length and age structures might be a valuable supplement in catch analyses, in combination with other population parameters such as age-length data for use in fishery management.

\section{ACKNOWLEDGEMENTS}

We want to thank the landowners who gave permission to sample fish in Lake Løyningsvatn. We highly acknowledge Jenny Stien for improving the English and two unknown referees for valueable corrections and suggestions for improving the manuscript.

\section{REFERENCES}

Amundsen P-A. 1988. Effects of an intensive fishing programme on age structure, growth and parasite infections of stunted whitefish (Coregonus lavaretus L. s.1.) in Lake Stuorajavri, northern Norway. Finnish Fishery Research 9: 425-434.

Amundsen P-A, Knudsen R, Klemetsen A. 2007. Intraspecific competition and density dependence of food consumption and growth in Arctic charr. Journal of Animal Ecology 76: 149-158. doi: 10.1111/j.1365-2656.2006.01179.x

Appelberg M, Berger HM, Hesthagen T, Kleiven E, Kurkilahti M, Raitaniemi J, Rask M. 1995. Development and intercalibration of methods in Nordic freshwater fish monitoring. Water Air Soil Pollution 85: 401-406.

Borgstrøm R. 1989. Direct estimation of gill-net selectivity for roach (Rutilus rutilus (L.)) in a small lake. Fisheries Research 7: 289-298. doi: 10.1016/0165-7836(89)90062-3

Borgstrøm R. 1992. Effect of population density on gillnet catchability in four allopatric populations of brown trout (Salmo trutta). Canadian Journal of Fisheries and Aquatic Sciences 49: 1539-1545. doi: 10.1139/f92-170

Borgstrøm R. 1994. Production in a lacustrine brown trout population with large recruitment potential and low natural mortality: implications for management. North American Journal of Fisheries Management 14: 488-499. doi: 10.1577/1548-8675(1994)014<0488:PIALBT>2.3.CO;2

Borgstrøm R, Museth J, Brittain JE. 2010. The brown trout (Salmo trutta) in the lake, Øvre Heimdalsvatn: long-term changes in population dynamics due to exploitation and the invasive species, European minnow (Phoxinus phoxinus). Hydrobiologia 642: 83-91. doi: 10.1007/s10750-010-0161-7

Borgstrøm R, Plahte E. 1992. Gillnet selectivity and a model for capture probabilities for a stunted brown trout (Salmo trutta) population. Canadian Journal of Fisheries and Aquatic Sciences 49: 1546-1554. doi: 10.1139/f92-171

Byström P, Persson L, Wahlström E, Westman E. 2003. Size- and density-dependent habitat use in predators: consequences for habitat shifts in young fish. Journal of Animal Ecology 2003: 156-168. doi: 10.1046/j.1365-2656.2003.00681.x

Byström P, Andersson J, Persson L, De Roos AM. 2004. Sizedependent resource limitation and foraging-predation risk tradeoffs: growth and habitat use in young arctic char. Oikos 104: 109-121. doi: 10.1111/j.0030-1299.2004.12759.x

Cerri RD, Fraser DF. 1983. Predation and risk in foraging minnows: balancing conflicting demands. The American Naturalist 121: 552-561. doi: 10.1086/284082

Christensen JM. 1964. Burning of otoliths, a technique for age determination of soles and other fish. Journal du Conseil Permanent International pour l'Exploration de la Mer. 26: 73-81. doi: 10.1093/icesjms/29.1.73

Damsgård B, Ugedal O. 2006. The influence of predation risk on habitat selection and food intake by Arctic charr, Salvelinus alpinus (L.). Ecology of Freshwater Fish 6: 95-101. doi: 10.1111/ j.1600-0633.1997.tb00149.x

Degerman E, Nyberg P, Appelberg M. 1988. Estimating the number of species and relative abundance of fish in oligotrophic Swedish lakes using multi-mesh gillnets. Nordic Journal of Freshwater Research 64: 91-100.

Forseth T, Næsje TF, Jonsson B, Hårsaker K. 1999. Juvenile migration in brown trout: a consequence of energetic state. Journal of Animal Ecology 68: 783-793. doi: 10.1046/j.13652656.1999.00329.x

Garcia-Berthou, E. 2001. Size- and depth-dependent variation in habitat and diet of the common carp (Cyprinus carpio). Aquatic Sciences 63: 466-476. doi: 10.1007/s00027-001-8045-6

Hamley JM. 1975. Review of gillnet selectivity. Journal of Fisheries Research Board of Canada 32: 1943-1969. doi: 10.1139/f75-233

Hamley JM. 1980. Sampling with gillnets. In: Backiel T and Welcomme RL (eds.). Guidelines for sampling fish in inlands waters. Eifac Technical Paper no. 33. FAO, Rome. pp. 37-53.

Hamley JM, Regier HA. 1973. Direct estimation of gillnet selectivity to walleye (Stizostedion vitreum vitreum). Journal of Fish Research Board of Canada 29: 1636-1638. doi: 10.1139/ f73-137

Haraldstad Ø, Jonsson B. 1983. Age and sex segregation in habitat utilization by brown trout in a Norwegian lake. Transactions of the American Fisheries Society 112: 27-37. doi: 10.1577/1548-8659(1983)112<27:AASSIH >2.0.CO;2

Hovgård H, Larssen H. 2000. Manual on estimation of selectivity for gillnet and longline gears in abundance surveys. FAO Fisheries Technical Paper No. 397. FAO, Rome. 84 p.

Jensen JW. 1990. Comparing fish catches taken with gill nets of different combinations of mesh sizes. Journal of Fish Biology 37: 99-104. doi: 10.1111/j.1095-8649.1990.tb05931.x

Jensen JW. 1995. A direct estimate of gillnet selectivity for brown trout. Journal of Fish Biology 46: 857-861. doi: 10.1111/j.1095- 
8649.1995.tb01608.x

Jensen JW, Hesthagen T. 1996. Direct estimates of the selectivity of a multimesh and a series of single gillnets for brown trout. Journal of Fish Biology 49: 33-40. doi: 10.1111/j.1095-8649.1996. tb00003.x

Jensen KW. 1972. Drift av fiskevann. Fisk og fiskestell 5. Direktoratet for jakt, viltstell og ferskvannsfiske, Trondheim. (in Norwegian). $61 \mathrm{p}$.

Jensen KW. 1977. On the dynamics and exploitation of the population of the brown trout Salmo trutta L. in Lake Øvre Heimdalsvatn, southern Norway. Report Institute of Freshwater Research Drottningholm 56: 18-69.

Jonsson B. 1989. Life history and habitat use of Norwegian brown trout (Salmo trutta). Freshwater Biology 21: 71-86. doi: 10.1111/ j.1365-2427.1989.tb01349.x

Jonsson B, Borgstrøm R. 2000. Fiskesamfunn i lavlandssjøer i Vest- og Midt-Norge. In: Borgstrøm R and Hansen LP (eds.). Fisk i ferskvann Et samspill mellom bestander, miljø og forvaltning. Landbruksforlaget, Oslo. pp. 83-88. (in Norwegian).

Klemetsen A, Amundsen P-A. 2000. Fiskesamfunn i nord-norske innsjøer. In: Borgstrøm $\mathrm{R}$ and Hansen LP. (eds.). Fisk $\mathrm{i}$ ferskvann Et samspill mellom bestander, miljø og forvaltning. Landbruksforlaget, Oslo. pp. 89-101. (in Norwegian).

Klemetsen A, Amundsen P-A, Grotnes PE, Knudsen R, Kristoffersen R, Svenning M-A. 2002. Takvatn through 20 years: long-term effects of an experimental mass removal of Arctic charr, Salvelinus alpinus, from a subarctic lake. Environmental Biology of Fishes 64: 39-47. doi: 10.1007/97894-017-1352-8_3

Klemetsen A, Amundsen P-A, Dempson B, Jonsson B, Jonsson N, Connell MF, Mortensen, E. 2003. Atlantic salmon Salmo salar L., brown trout Salmo trutta L. and Arctic charr Salvelinus alpinus (L.): a review of aspects of their life histories. Ecology of Freshwater Fish 12: 1-59. doi: org/10.1034/j.16000633.2003.00010.x

Kurkilahti M, Appelberg M, Bergstrand E, Enderlein O. 1998. An indirect estimation of bimodal gillnet selectivity of smelt. Journal of Fish Biology 52: 243-250. doi: 10.1111/j.10958649.1998.tb00796.x

Kurkilahti M, Rask M. 1996. A comparative study of the usefulness and catchability of multimesh gill nets and gill net series in sampling of perch (Perca fluviatilis L.) and roach (Rutilus rutilus L.). Fisheries Research 27: 243-260. doi: 10.1016/01657836(95)00463-7

L’Abée-Lund JH, Langeland A, Jonsson B, Ugedal O. 1993. Spatial segregation by age and size in Arctic charr: a trade-off between feeding possibility and risk of predation. Journal of Animal Ecology 62: 160-168. doi: 10.2307/5490

L’Abée-Lund JH, Langeland A, Sægrov H. 1992. Piscivory by brown trout Salmo trutta L. and Arctic charr Salvelinus alpinus (L.) in Norwegian lakes. Journal of Fish Biology 41: 91-101. doi: 10.1111/j.1095-8649.1992.tb03172.x

Lagler KF. 1968. Capture, sampling and examination of fishes. In: Ricker WE (ed.). Methods in assessment of fish production in fresh waters. Blackwell, Oxford. pp. 7-45.

McCombie AM, Fry FEJ. 1960. Selectivity of gill nets for lake whitefish, Coregonus clupeaformis. Transactions of the American Fisheries Society 89: 176-184. doi: 10.1577/15488659(1960)89
Museth J, Borgstrøm R, Brittain JE, Herberg I, Naalsund C. 2002. Introduction of the European minnow into a subalpine lake: habitat use and long-term changes in population dynamics. Journal of Fish Biology 60: 1308-1321. doi: 10.1006/ jfbi.2002.1951

O'Grady MF. 1981. Some direct gillnet selectivity tests for brown trout Salmo trutta L. populations. Irish Fisheries Investigations Series A 22: 3-9.

Qvenild T, Skurdal J. 1981. Garnseleksjon for sik ved prøvefiske med flytegarn i Tyrifjorden. Fauna 34: 110-115. (in Norwegian with English abstract).

Regier HA, Robson DS. 1966. Selectivity of gill nets, especially to lake whitefish. Journal of the Fisheries Research Board of Canada 23: 423-454. doi: 10.1139/f66-034

Ricker WE. 1975. Computation and interpretation of biological statistics of fish populations. Bulletin 191. Department of the Environment Fisheries and Marine Service, Ottawa. 382 p.

Rudstam LG, Magnuson JJ, Tonn WM. 1984. Size selectivity of passive fishing gear: a correction for encounter probability applied to gill nets. Canadian Journal of Fisheries and Aquatic Sciences 41: 1252-1255. doi: 10.1139/f84-151

Sandlund OT, Næsje TF, Jonsson B. 1992. Ontogentic changes in habitat use by whitefish (Coregonus lavaretus). Environmental Biology of Fishes 33: 341-349. doi: 10.1007/BF00010945

Schei TA, Jonsson B. 1989. Spatial distribution of allopatric brown trout in the Lake Oppheimsvatnet, Voss, Norway. In: Brannon EL and Jonsson B (eds.). Migration and distribution of salmonids. Proceedings of an international Symposium. University of Washington, School of Fisheries, Seattle, USA. pp. 156-167.

Svenning M-A, Borgstrøm R. 2005. Arctic charr: do all individuals have the same propensity to be cannibals. Journal of Fish Biology 66: 957-965. doi: 10.1111/j.1095-8649.2005.00646.x

Sømme, ID. 1941. Ørretboka. Jakob Dybwads Forlag, Oslo. (in Norwegian). 591 p.

Werner EE, Gilliam JF, Hall DJ, Mittelbach GG. 1983. An experimental test of the effects of predation risk on habitat use in fish. Ecology 64: 1540-1548. doi: 10.2307/1937507

Werner EE, Hall DJ. 1988. Ontogenetic habitat shifts in bluegill: the foraging rate-predation risk trade-off. Ecology 69: 13521366. doi: $10.2307 / 1941633$

Woillez P, Walline PD, Ianelli JN, Dorn MW, Wilson CD, Punt AE. 2016. Evaluating total uncertainty for biomass- and abundance-at-age estimates from eastern Bering Sea walleye Pollock acoustic-trawl surveys. ICES Journal of Marine Science 73:2208-2226. doi: 10.1093/icesjms/fsw054

Editorial responsibility: Jan Grimsrud Davidsen.

This article is open-access and distributed under the terms of the Creative Commons Attribution 4.0 International license. This permits all non-commercial use, distribution, and reproduction in any medium, provided the original work is properly cited. (http://creativecommons.org/licenses/by/4.0/). 